\title{
From Typographer to Graphic Designer: Typographic Exhibitions and the Formation of a Graphic Design Profession in Canada in the 1950s and 1960s
}

\section{Cheryl Dipede}

Volume 40, numéro 2, 2015

Design Studies in Canada (and beyond) : The State of the Field

Les études du design au Canada (et au-delà) : un état des lieux

URI : https://id.erudit.org/iderudit/1035401ar

DOI : https://doi.org/10.7202/1035401ar

Aller au sommaire du numéro

\section{Éditeur(s)}

UAAC-AAUC (University Art Association of Canada | Association d'art des universités du Canada)

ISSN

0315-9906 (imprimé)

1918-4778 (numérique)

Découvrir la revue

Citer cet article

Dipede, C. (2015). From Typographer to Graphic Designer: Typographic Exhibitions and the Formation of a Graphic Design Profession in Canada in the 1950s and 1960s. RACAR : Revue d'art canadienne / Canadian Art Review, 40(2), 130-145. https://doi.org/10.7202/1035401ar

\section{Résumé de l'article}

Cet article explore le développement d'une communauté professionnelle de design au Canada pendant les années 1950 et 1960 en examinant deux collaborations entre graphistes : les expositions canadiennes Typography (1958-1964) et l'exposition internationale Typomundus 20 (1963-1966). Celles-ci contribuèrent à la publicisation d'un nouveau discours qui permit aux typographes et aux concepteurs de la communication canadiens de se penser comme faisant partie d'une communauté unifiée et distincte de "graphistes ". Elles encouragèrent cette cohésion professionnelle notamment en avançant des normes professionnelles, en lançant une réflexion sur le statut et le rôle du graphisme par rapport au " grand » art, à la communication de masse et à la société en général, et en facilitant l'échange d'idées entre les professionnels canadiens et la communauté internationale de graphistes.
Tous droits réservés (C) UAAC-AAUC (University Art Association of Canada | Association d'art des universités du Canada), 2015
Ce document est protégé par la loi sur le droit d'auteur. L'utilisation des services d'Érudit (y compris la reproduction) est assujettie à sa politique d'utilisation que vous pouvez consulter en ligne.

https://apropos.erudit.org/fr/usagers/politique-dutilisation/ 


\title{
From Typographer to Graphic Designer: Typographic Exhibitions and the Formation of a Graphic Design Profession in Canada in the 1950 s and 1960 s
}

\author{
Cheryl Dipede
}

\begin{abstract}
Cet article explore le développement d'une communauté professionnelle de design au Canada pendant les années 1950 et 1960 en examinant deux collaborations entre graphistes: les expositions canadiennes Typography (1958-1964) et l'exposition internationale Typomundus 20 (1963-1966). Celles-ci contribuèrent à la publicisation d'un nouveau discours qui permit aux typographes et aux concepteurs de la communication canadiens de se penser comme faisant partie d'une communauté unifiée et distincte de "graphistes». Elles encouragèrent cette cohésion professionnelle notamment en avançant des normes professionnelles, en lançant une réflexion sur le statut et le rôle du graphisme par rapport au "grand» art, à la communication de masse et à la société en général, et en facilitant l'échange d'idées entre les professionnels canadiens et la communauté internationale de graphistes.
\end{abstract}

Cheryl Dipede is a book designer currently living in Cambridge, UK. -cdipede@gmail.com

1. This article is adapted from a Major Research Paper titled "Canadian Graphic Design in the 1950 s and 1960s: The Shaping of a Profession," submitted to OCAD University in 2012.

2. The new design was inaugurated and adopted for use as the first Canadian national flag in 1965.

3. Commissioned by the Canadian government and named after Jacques Cartier, the French explorer of Canada, Dair's typeface Cartier is considered the first Latin typeface designed in Canada.

\section{Introduction and Background}

The 1950 and 1960 s were pivotal decades in the forging of graphic design as a self-standing profession. ${ }^{1}$ They were also crucial years for the emergence of a Canadian national identity and for the rise of a mass global culture. This article explores the growth of a professional design community in Canada in the 1950 and 1960 s and seeks to establish how a sense of professional identity emerged among Canadian graphic designers of this period. Specifically, two case studies of collaboration among graphic designers help illuminate the ways in which graphic design in Canada was both shaped by and participated in larger social and cultural developments. The Typography exhibition series, held in Canada between 1958 and 1964, and Typomundus 20, an international exhibition that took place in 1963-1966, where Canadian designers played key roles, contributed to social cohesion, and helped define the identity of graphic designers and the profession in Canada during the period. Professional identity was galvanized through debates concerning style, the cultural status of design, and broader social values. At the same time, gaps appeared between the stated ambitions of exhibition organizers and the actual judging practices of Typomundus 20. Ironically, these gaps served to further social cohesion among graphic designers of the period.

During the 1950 s and 1960 s the Canadian graphic design community was engaged in an increasing number of projects that would prove pivotal to the nation's visual identity. Among these projects were individual design works such as a new logo for the Canadian National Railway designed by Allan Fleming in 1959, and an Air Canada logo designed by Hans Kleefeld in 1964. As primary national symbols, the design of the Canadian flag in $1964^{2}$ and Jim Donahue's design of the Canada Wordmark in 1965 contributed directly to the building of a national identity. Larger cultural events, such as the International and Universal Exposition (Expo 67) and celebrations of the Canadian centenary in 1967, had strong graphic design components, including the Expo logo, designed by Julien Hébert, | fig. 1 | the Canadian centennial maple leaf symbol, designed by Stuart Ash, | fig. 2 | and Carl Dair's typeface design Cartier. ${ }^{3}$ These and other design projects such as the Federal Identity Program of $1968^{4}$ were instrumental attempts by the Canadian government to establish symbols of Canadian sovereignty in the postwar period that were distinct from the previously dominant British influence. 
Figure 1 (left). Julien Hébert, Expo 67 logo, ca. 1967. Source:

"Expo 67 in Montreal, a Landmark Event," Online Encyclopedia offrench Cultural Heritage in North America, Ville de Montréal, Gestion de documents et archives, www.ameriquefrancaise.org/en.

Figure 2 (right). Stuart Ash, Centennial Maple Leaf, 1966. Source: "Centennial Logo," The Canadian Design Resource, www.canadiandesignresource.ca.
4. Michael Large, "The Corporate Identity of the Canadian Government," Journal of Design History 4, 1 (1991): 31-42, esp. 32.

5. The transition to offset lithography, accompanied by an increase in photographic composition, would itself be supplanted by electronic and digital data handling in the 1970 s and 1980 s. See Bryan Dewalt, Technology and Canadian Printing: A History from Lead Type to Lasers (Ottawa, 1995), 119.

6. Robert Stacey, "Graphic Art and Design," Canadian Encyclopedia, Online Edition, http://thecanadianencyclopedia.com/en/article/ graphic-art-and-design/.
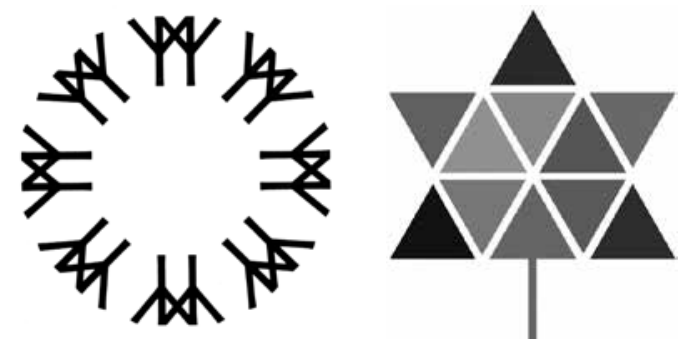

The rise of the mass market and new mass communication technologies in the postwar period had a similarly positive effect on the growth of the graphic design profession in Canada. Design was supported by new methods of production in the printing industries, facilitating higher rates of production at lower costs to support greater demands for an ever-increasing number of goods and services.

The systematic automation of hot metal typography, and later the transition to photographic ${ }^{5}$ methods of reproduction, had a polarizing effect on the historical profession of the typographer. Some typographers became specialized machine operators, and almost completely abandoned the creative aspect of their profession. Others increasingly specialized in the creative aspect of typesetting and eventually left the press altogether to take up work in studios. At the same time, commercial designers were increasingly able to exercise greater control over typographic layout, thanks to the accessibility of typographic design in the photographic medium. It is these two latter groups-the creative typographers and the commercial designers-cum-typographers-that became first typographic designers and eventually adopted the designation graphic designers.

Changing attitudes among commercial artists and typographers toward their professions led to the formation of societies and clubs in which those attitudes were shared and debated. Organizations such as the Society of Typographic Designers of Canada (TDC), the Art Director's Clubs of Toronto (founded 1948), and the Société des graphistes du Quebec (founded 1972) provided a forum for discussion of professional interests, including debates concerning the title of the new profession. The development of the design profession in Canada during the 1950 s was eventually rewarded by recognition from Canada's governmental funding agencies with the creation of the National Design Council in 1961 , on the recommendation of the TDC. ${ }^{6}$

In addition to national and professional considerations, a number of internationalist trends were influential among Canadian designers during the postwar period. The formation of international design organizations such as the International Center for the Typographic Arts (ICTA) in New York and the International Council of Graphic Design Associations (Icograda) in London, in 1960 and 1963 respectively, was intended to promote international cooperation among designers and foster ideas of design as a socially responsible cultural agent. Visionaries such as Marshall McLuhan and C. Wright Mills fed the postwar social consciousness on ideas of future society as a "global village," promoting an alternative form of democracy that embodied a rational, utopian liberalism. In this environment, designers were energized by a belief in their 
7. Relevant publications by the Society of Typographic Designers of Canada (henceforth TDC) are The Constitution (Toronto, 1956); Announcing: Typography 58 (Toronto, 1957); Typography 58 (Toronto, 1958); Typography 59 (Toronto, 1959); Typography 60 (Toronto, 1960); Typography 61 (Toronto, 1961); Typography 62 (Toronto, 1962); Format (Toronto 1963); and Typography 64 (Toronto, 1964).

8. TDC 1957

9. TDC 1957

10. TDC 1957.

11. Brian Donnelly, "Mass Modernism: Graphic Design in Central Canada, 1955-1965, and the Changing Definition of Modernism," MA thesis, Carleton University, 1997,80 .

12. As discussed further below, the label "typographic designer" eventually morphed into the designation of "graphic designer." power to promote global harmony and understanding. Large-scale exhibitions presented during the 1950 s at important cultural institutions such as New York's Museum of Modern Art (MoMA) reinforced such notions by stressing international humanist ideals. The Family of Man (1955) photographic exhibition, which included the work of 273 photographers from 68 countries, and the Good Design (1950-55) series of exhibitions highlighting works of industrial and product design are two examples. Postwar designers were thus embedded in a cultural atmosphere that encouraged them to strive for more socially progressive ideals and to view their own work as serving such ideals, at least in part. An additional factor linking the Canadian design community to international trends was the postwar immigration of Europe-trained designers to Canada. The presence of émigré designers resulted in professional organizations and in a Canadian design community that was international in composition. This diversity played an important role in the organization of the Canadian Typography exhibitions during the 1950s and 1960 s.

\section{Canadian Typography Shows}

The Canadian Typography exhibitions were a series of national shows that took place between 1958 and 1964. The Toronto-based national design organization, the TDC, organized the six, juried exhibitions in conjunction with the Rolland Paper Company. ${ }^{7}$ The stated mandate for the shows was to "gather and evaluate examples of Canadian typographic design ... reward those of outstanding merit ... [and] display the best examples" from the preceding one- or two-year period. ${ }^{8}$ The Typography exhibitions allowed the TDC to pursue its larger aim to build a professional status for designers by "encouraging higher standards" in printed communication, and "stimulating public appreciation" for the profession. ${ }^{9}$ In addition to a national and international travelling exhibition, each Typography show produced its own printed catalogue and other ephemera, including calls for submissions, invitations, and printed menus to accompany formal awards dinners. | fig. 3 | The printed catalogues in particular were intended as "a source of inspiration and guidance" for designers working in the related fields of commercial art, advertising, printing, and publishing. ${ }^{10}$ These catalogues and their content would ultimately play a larger role in unifying these sister professions under the umbrella term of graphic designer.

As the Canadian design community grew and developed over the period of the exhibitions, so too the number of submissions for these exhibitions increased and the categorical divisions developed to reflect the expansion of the profession. The initial Typography 58 show, for example, attracted 1,250 submissions, while the final Typography 64 received 2,272 submissions from designers and students across the country. ${ }^{11}$ The increase in submissions reflected a diversification of categories, which allowed craftsmen working in the previously distinct roles of typographer, typesetter, book designer, art director, layout artist, commercial artist, and even students to think of their work as falling under the unified classification of typographic design. ${ }^{12}$ Typography 58 began with just three competitive categories for works of "Canadian book design," "Canadian business printing," and "Canadian magazine design." In its final year the exhibition had expanded to include additional categories for 
Figure 3. Printed Ephemera. Clockwise from bottom left: Typography 58 Call for Submissions; Typography 62 Awards Dinner Menu; Typography 62 Extended Call for Submissions. All three items from the personal archive of Brian Donnelly (photo: author).
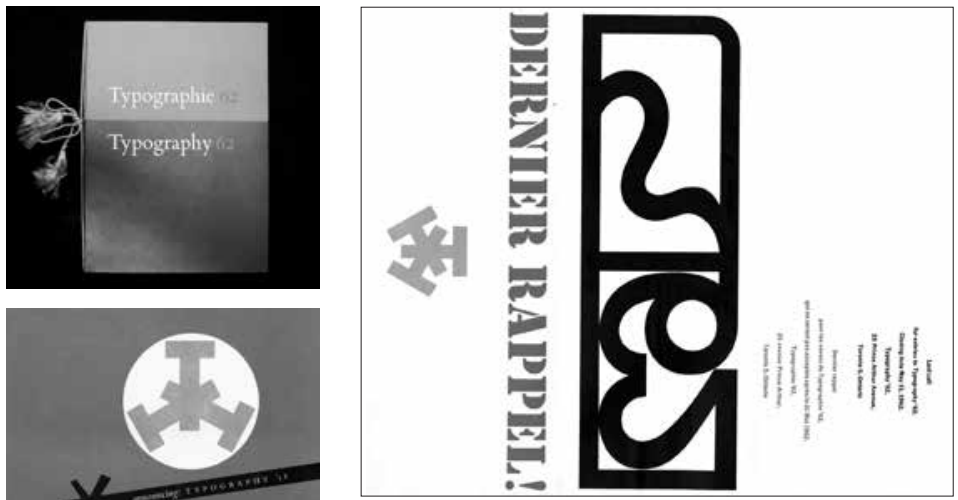

experimental design and student work, among others. The addition of these new categories expressed a trend toward forms of production with less direct ties to the market and an interest in fostering future growth in the profession through education.

In addition to images of the award-winning entries, each Typography catalogue included written commentary from both TDC members and contemporary designers not directly involved in the exhibition's organization. Introductory essays, statements from the judges, and closing messages from the current president of the TDC addressed the state of the profession and promoted reflection on various aspects of the social, professional, and artistic role of the designer. These articles and the ideologies they promoted made the Typography exhibitions significant internal sites of disciplinary definition and change. Whereas businesses, governments, and consumers were the primary audience for works of graphic design in the pre- and immediate postwar decades, with the Typography exhibitions and their supporting printed matter the audience for the exhibited works shifted toward the design community and designers themselves. The Typography exhibitions communicated associations of aesthetic value and quality to the selected works and ascribed a status above ephemera to the selections.

This increased reflection on designers' products was inextricably linked to the aim of obtaining wide public recognition of the new profession. Situating works of graphic design within high-cultural contexts including museums, libraries, art galleries, and universities allowed show organizers to achieve this goal. Award-winning entries from the fourth annual competition, Typography 61 , for example, hung for two weeks at the Royal Ontario Museum in Toronto, and spent a further four weeks on display at the Montreal Museum of Fine Arts. In other years Typography's exhibition venues included the Ontario Architectural Association, the Canadian National Exhibition, and the Vancouver Art Gallery. Through their contextualization within these venues, the exhibited design works acquired new value in their role as exemplars of professional standards. The aura of the artwork and its associations with formal "purity" and disinterested autonomy elevated these works of design by distancing them from their original commercial settings and associations with the marketplace. 
13. TDC 1959, 57.

14. TDC $1960,58$.

15. TDC 1961, 69 .

6. TDC 1962, 7 .

7. Carl Dair, "Carl Dair, Canada," Print 18, 1 (January 1964): 85.

18. Dair, "Carl Dair," 85. Dair's call echoes other examples of utopian-inspired initiatives from the same period, such as those proposed by Rudolf Modley and Margaret Mead. For discussion see Keith Bresnahan, "An Unused Esperanto: Internationalism and Pictographic Design, 1930-70," Design and Culture 3, 1 (2011): 5-24.

19. Carl Dair, "Why Typography," Canadian Art 87 (September) October 1963): 291 .

20. TDC 1960,57 .
The organizers of the Typography shows were not solely concerned with the advancement of the profession at the time, but also with the need to adequately educate the next generation of Canadian designers. In his essay at the end of the 1959 catalogue, Canadian designer Allan Fleming commented on the current state of design education in Canada and argued for educational subsidies and better training for students of typography. ${ }^{13}$ Frank Davies echoed the call for better design education the following year, concluding his essay “Why All This Fuss About Typographic Design?" with an appeal for better training for designers, so as to enable consistently rising standards of work. ${ }^{14}$ This advocacy for design education may have inspired the inclusion of the first "Student Entries" category in Typography 60. In his introduction to the new category, Canadian designer and Typography juror Carl Dair noted apparent progress in the incorporation of design training by Canadian art schools, ${ }^{15}$ while Pieter Brattinga praised the Canadian Typography exhibitions for "select[ing] and print[ing] student work together with the work of professionals" the following year. ${ }^{16}$ The development of the student category under the umbrella of the Typography exhibitions serves as an example of the professionalization operating at the heart of the Canadian design community during this period.

As a professional forum, the Typography exhibitions also prompted reflection on the social role of the designer as one that included new responsibilities to larger human values and ideals. In an article published in a 1964 issue of Print magazine, Carl Dair expressed the necessity for a broader social role for the typographer that would serve utopian social aims. ${ }^{17}$ Noting that "the typographer cannot escape involvement in the social problems of his epoch," Dair advocated communication design as a panacea that would bridge "barriers of race, religion, language, politics, and economics ... and give the human race a common basis of communication, and from this, understanding and tolerance." ${ }^{18}$ As an organizing member and judge of the Typography exhibitions from the beginning, Dair's optimism toward the designer's agency to effect positive social change was influential. In his address on the opening of the Typography 62 exhibition, Dair had previously noted the power of good typographic design to impact society at large and "greatly enrich our lives...in our relations with our fellow inhabitants of this planet." 19

By promoting reflection on the social role of the designer, the Typography exhibitions strengthened the Canadian design community's sense of itself as connected to an international design community and its aims, in addition to the local goals of professionalization and development of Canadian design standards. "Typographic design is now thoroughly international," declared Frank Davies in an essay included in the Typography 60 catalogue. ${ }^{20}$ The essays and commentary included in the Typography catalogues often concerned international design trends, with extensive discussion of the Swiss International Typographic Style of design (hereafter the International Style), and its impact on notions of a national style in the later years of the exhibitions. Written contributions to the exhibition catalogues by American and European designers further connected the Canadian design community to international debates by offering a global perspective on the state of the profession. The catalogue for Typography 61 included an introductory article by the prominent American designer Aaron Burns, discussing typographic developments in places such as 


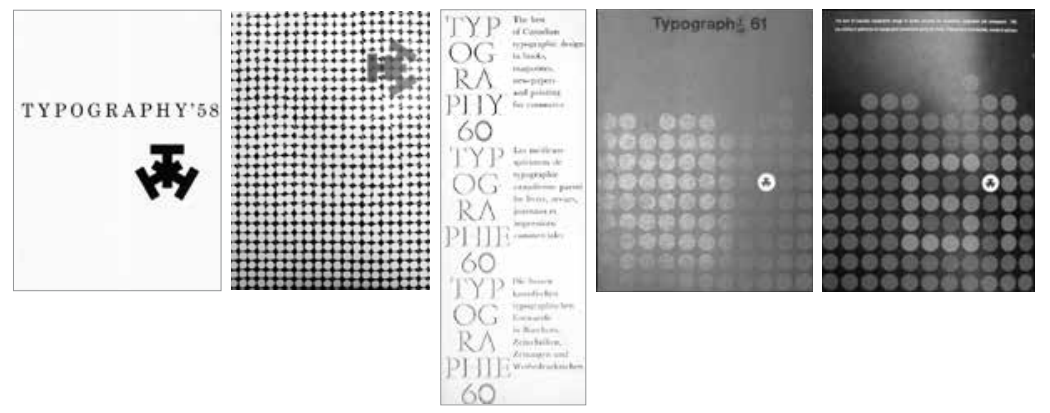

Figure 4. Selected Typography catalogue covers. From left: Leslie Smart, Typography 58 ; Frank Newfeld, Typography 59; Frank Davies, Typography 60; Jack Birdsall, Typography 61 (front and back). Sources: 58 from the author's personal collection; 59 $\& 60$ from the personal archive of David Michaelides; 61 from the personal archive of Brian Donnelly (photo: author).

Czechoslovakia, Japan, and Holland. Burns noted North American designers' excitement in discovering these "new cultures with different forms of communication that truly present new and challenging problems to the designer." ${ }^{21}$ The catalogue accompanying Typography 62 similarly opened with an article written by a non-Canadian designer, Dutch-American Pieter Brattinga, who noted that, "designs which are executed today in a far corner of the world will be known to us in a few weeks." 22 The Typography catalogues containing these statements themselves participated in the developments they describe, bringing information and opinions from the wider world to the Canadian design community and bringing Canadian design to the attention of both national and international audiences.

The influx of postwar immigrants to Canada made the country a fertile ground for international crosspollination and collaboration. Between 1951 and 1965 Toronto and Montreal in particular benefitted from a wave of immigration by designers from England, Germany, Switzerland, and other European countries. German émigrés Rolf Harder (emigrated 1952), Hans Kleefeld (1952), Peter Dorn (1953), Ernst Barenscher (1958), and Gerhard Doerrie (1961) brought training and ideas from their native countries to their new Canadian communities. The participation of these designers in the growth of the Canadian design profession reinforced that community's self-image as thoroughly international. Indeed, all four founding members of the TDC were recent immigrants to Canada who had trained in Great Britain. Frank Davies, John Gibson, Sam Smart, and Frank Newfeld ${ }^{23}$ came to Canada from England between 1951 and 1954, and held the first meeting of the new society of designers at the Arts and Letters Club in Toronto in $1956 .{ }^{24}$ Through its role as the organizing body of the Typography shows, the TDC redeployed this image of

21. TDC 1961, 7 .

22. TDC 1962, 7.

23. Unlike Davies, Gibson, and Smart who were British nationals, Newfeld was born in Czechoslovakia and immigrated to England with his family as a child. See Frank Newfeld, Drawing On Type (Erin, on, 2008), 9 .

24. Donnelly, "Mass Modernism," 57.

25. Brian Donnelly, "Locating Graphic Design History in Canada," Journal of Design History 19, 4 (2006): 283-94, 292. cultural diversity within the wider Canadian design community.

\section{Developing Aesthetic Criteria}

Concomitant with reflection on their societal and cultural roles, Canadian graphic designers of this period hotly debated the stylistic principles governing their work. A key topic of interest among postwar graphic design communities was the increasing popularity of the International Style and the meaning of this trend for Canadian designers. Indeed, Brian Donnelly notes that the International Style was the "single great reference point for the description of postwar design" among Canadian designers of the period. ${ }^{25}$ 
26. Leslie Smart, "Canadian Book Design," Royal Society for the Encouragement of Arts, Manufactures and Commerce Journal 116, 5146 (September 1968): 864-77, 872 .

27. Smart, "Canadian Book Design," 873 .

28. TDC 1964, 7 291.
The International Style was a formal system for combining images and text that promoted objectivity, rationality, and standardization through means such as sans-serif typography, clean lines and grids, and the use of photography over illustration.

Much evidence of the increasing influence of the International Style on Canadian designers can be found in the debates and products of the Typography exhibitions. Catalogues and articles written over the period of the exhibitions illustrate a progressive adoption of design methods associated with the Style, and a concurrent sense of professional development. Reviewers of the period noted that Canadian design transformed from "dull and old fashioned" ${ }^{26}$ prior to Typography 58 , to progressively more experimental, innovative, and finally, rational, and that the Typography 64 exhibition was "the best of the Typography shows that has ever been mounted." ${ }^{27}$ While earlier exhibitions featured works drawn from a variety of influences, Typography 64 showed a greater number of works in the International Style among both its award-winning entries and in the design of its catalogue. Prior to 1964, the Typography catalogue exteriors reflected a range of design styles, featuring serifed fonts and an eclectic use of space and colour. | fig. $4 \mid$ By contrast, the cover of the Typography 64 catalogue employed the newly designed sans-serif font Helvetica, and further deviated from its predecessors by virtue of its square shape and grid-based asymmetrical layout. | fig. 5 |

While the catalogue exterior delighted in the International Style, debates within the catalogue show that Canadian designers did not universally embrace the new style. Influential Canadian designer and TDC member Allan Fleming lamented the overreliance on the "safely anonymous" International Style in the submitted works and expressed concern at the loss of diversity and experimentation. ${ }^{28}$ Fleming cautioned against the standardization inherent in a truly international design style, hinting at the conflict between global uniformity and Canadian identity.

In addition to these concerns, the Typography exhibitions also promoted reflection on distinctions between art and craft and between form and function. In so doing, they focused the attention of the design community on the shifting role of the typographer, to that of typographic designer, and eventually graphic designer. Technological changes in the production methods of the time allowed typographers to dedicate themselves to the creative aspects of their work, and hence freed them to contemplate its aesthetic qualities. Many Canadian postwar designers saw beauty and form as instrumental to communication in the craft of typographic design. In an address given on the occasion of the opening of the Typography 62 exhibition, Dair noted that, "the form of the letter ... is an object of aesthetic satisfaction, and the weaving of a page of type an exercise in artistic skill." ${ }^{29}$ By promoting reflection on the aesthetic value of typography, Dair was implicitly encouraging typographers to think of themselves as designers rather than craftsmen. Typographers now had the freedom to choose whether and how much they valued functionality, and the appropriate limits of this newly found freedom had to be settled through discussion and debate. Nonetheless, Dair ultimately defined the role of these beautiful forms as being in the service of their communicative function. Although he praised the need for aesthetic beauty, he was not concerned 


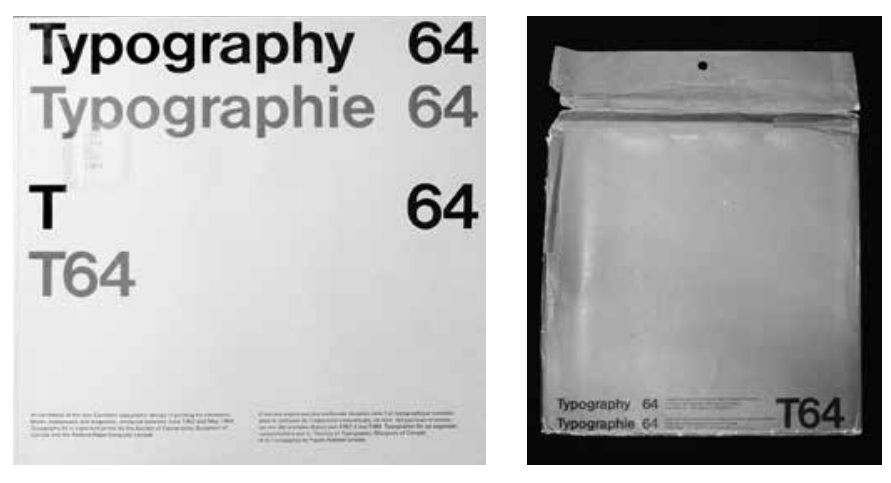

30. Ibid.

31. Smart, "Canadian Book Design," 873 .

32. Gilles Hénault, "Reflections On Seeing Typography 62," Canadian Art 87 (September/October 1963): 288-90, esp. 289.

33. Beatrice Warde, The Crystal Coblet: Sixteen Essays on Typography (Cleveland, 1956).

34. TDC 1959, 57.

35. TDC 1960, 55 .

36. TDC 1960,51 .

37. TDC 1960, 55.

38. TDC 1961,3 .

39. TDC 1961, 8.

40. TDC 1964,75 . with typographic beauty as a spiritual experience, but with the knowable and concrete aspects of typographic beauty and the measures of its formal construction, including proportion, subtlety of line, good form, and discriminating taste. ${ }^{30}$

Other Canadian designers also weighed in on the debate concerning design's commitment to functionality. Canadian designer and TDC founding member Leslie Smart noted that he was "disappointed that the catalogues had a tendency to ... glamorize rather than be a functional reference, which, after all, is what they should be." ${ }^{31}$ French-Canadian journalist and poet Gilles Hénault took the opposing position. Reacting to what he classified as Dair's functionalist position, Hénault's message was that the pursuit of beauty itself was a vital process of communication, beyond instrumental considerations. ${ }^{32}$ Hénault's argument against Dair was also implicitly an argument against typographer Beatrice Warde's well-known 1956 essay "The Crystal Goblet,"33 which bound the value of typography to its function.

Debates concerning the divide between art and craft also played out in the pages of the Typography catalogues. Allan Fleming decisively located typography at the applied end of the art-craft spectrum, referring to it as a craft or trade in his essay for the 1959 Typography catalogue. ${ }^{34}$ Expressing the opposite position in the following year, Frank Davies suggested that letterforms could be made to convey supplemental meaning to the text in the hands of a skilled typographer. ${ }^{35}$ Referring to "graphic design," ${ }^{36}$ Davies likened this successful approach to artistry that was "at its purest, a form of poetry." ${ }^{37}$ Here Davies uses the term graphic design as a rhetorical tool to explicitly distance typography from craft. In the 1961 catalogue TDC President William Toye stated that, unlike pictures in an art gallery, "typographic design is a craft not an art." 38 Aaron Burns, by contrast, called attention to the indeterminate status of the shifting professional field. In his essay "Where Are We Going?" Burns noted that typographers themselves were still uncertain as to the limits of their field, but that "typography is more than it was before." ${ }^{39}$ Three years later, the profession was still struggling to define its boundaries. While the foreword to Typography 64 boldly proclaimed typographic design to be an art, TDC president Gerry Moses continued to refer to typographic design as a craft in the catalogue's concluding message. ${ }^{40}$ There was clearly a lack of consensus among these designers on the definition of typographic design and the role of the 
41. Donnelly, "Mass Modernism," 63 .

42. Burton Kramer, "Graphic Design in Canada," Idea 115 (extra issue, 1975) as quoted in Donnelly, "Mass Modernism," 64. designer, in relation to the art/craft distinction. At stake for the profession was the loss of its relationship to its traditional roots in the craft of letterpress typography. This association with art also caused concern among those who saw a danger in losing what was unique about design-its functional aspectsin an attempt to gain cultural status. A closely related topic of discussion was the nature of experiment versus communication in typographic design. Design of an experimental, rather than functional, nature was recognized by the exhibitions with the introduction of the "Experimental Typography" category in 1961. With the creation of this category the Typography exhibitions sought to encourage an association with the "free" status of high art, with an emphasis on the aesthetic rather than the communication value of the works.

On the whole, the Typography exhibitions' focus on aesthetic-based judging rewarded the formal, artistic qualities of the works and disregarded success as communication intended to extend commodity production and consumption. By recontextualizing commercial artefacts as aesthetic objects, the exhibitions succeeded in expanding the definition and value of works of design and promoting a broader understanding of the profession among the national design community and to a wider public. Despite this success, the majority of works exhibited under the Typography banner remained inextricably linked to commercial interests by virtue of content tied to their clients' products. Additionally, the sought-for distancing of design from commerce ironically clashed with the fate of the shows themselves. The Typography exhibitions retained and indeed relied upon their connection to industry through the supporting role played by sponsor Rolland Paper, until eventually the exhibitions came to an end with the withdrawal of this sponsorship in 1966.

Although the Typography exhibitions were only staged a handful of times over a short number of years, the discussions of national and international community and ideological divisions between art and design, as well as the debates concerning form and function that surrounded them participated in an important shift in the nature of the graphic design profession in the postwar period. Ideas regarding a greater artistic autonomy and an expanded social role for the designer promoted a new identity for the graphic designer as a figure who would henceforth be responsible to society at large, and not simply to the commercial interests of clients. Perhaps not incidentally, the term graphic designer began to predominate around the same time. Designers who had previously considered themselves typographic designers eventually dropped the typo in order to reflect the expanded role of the professional designer in the media revolution underway in society at large. In 1967, then-TDC president John Gibson solicited members' opinions on the state of the design profession, ${ }^{41}$ following which the Society of Typographic Designers of Canada (TDC) renamed itself the Society of Graphic Designers of Canada (GDC) in 1968. This reflected the change in the professional identity and status of designers whose work now encompassed "all aspects of visual communication" in the minds of its membership. ${ }^{42}$

\section{Typomundus}

The international typographic exhibition Typomundus 20 (henceforth Typomundus) that spanned the years 1963-1966, provides the opportunity for a similar 
43. National Art Education Association, "News of the Profession," Art Education 16, 9 (December 1963): 27-30.

44. Ibid., 27.

45. International Center for the Typographic Arts (henceforth ICTA), Typomundus 20, (New York, 1966). Unpaginated catalogue with paginated forward. The quotation is from $p$. VII.

46. Sadly, many of the original submissions were lost or destroyed when mistaken for trash at the storage facility on Bloor Street in Toronto, which was emptied due to unpaid rent (http://www.thestar.com/news/gta/2015/01/30/ forgotten-toronto-history-thattime-an-impressive-collectionof-2oth-century-typography-wasthrown-in-the-trash.html).

47. Judges: Max Caflisch (Switzerland), Carl Dair (Canada), Lou Dorfsman (USA), Olle Eksell (Sweden), Roger Excoffon (France), Hiromu Hara (Japan), Oldrich Hlavsa (Czechoslovakia), Hans Neuburg (Switzerland), Anton Stankowski (Germany), Horst Erich Wolter (Germany), Hermann Zapf (Germany), and Piet Zwart (Netherlands). Organizers: Paul Rand, Honorary Chairman (USA), Aaron Burns, Director of the Internationa Center for the Typographic Arts (USA), and Marilyn Hoffner, Publicity Committee (USA).

48. Donnelly, "Mass Modernism," 61.

49. Correspondence relating to the relocation of Typomundus, as well as a wealth of documentation on both Typomundus and the Typography exhibitions can be found in the Carl Dair papers at the Robertson Davies Library, Massey College, University of Toronto. analysis to that performed on the Canadian Typography exhibitions. Typomundus operated at a larger scale than the Typography exhibitions in terms of both numbers of submissions and geographical reach. More importantly, Typomundus achieved professional cohesion mainly through exclusion and by limiting the variety of possible typographic styles.

Typomundus was an international travelling exhibition of juried typographic design works that sought to represent a collected world of typography as art. Conceived under the auspices of ICTA (the International Center for the Typographic Arts in New York), Typomundus drew approximately 10,000 submissions from countries around the world from its initial call for entries in 1963 . The exhibition notice announced the show's aim to be "the first worldwide exhibition of the most significant typography of the $20^{\text {th }}$ century." 43 Initial submissions were sent to Toronto, where, in October of 1964 a jury of "design experts" 44 made up of Swiss, Swedish, Dutch, German, French, Japanese, Slovakian, Canadian, and American judges spent a week selecting 612 individual works for inclusion in the show. Typomundus's mandate also included the creation of a permanent archive at ICTA's offices in New York both to house the selected entries and to serve as "a research centre for designers, educators, and students." 45 Typomundus thus represented the ambitions of an international organizing body to not merely display but to gather, preserve, and document a global history of typographic design for the first sixty years of the twentieth century. ${ }^{46}$

A bound, book-length catalogue of the exhibition published in 1966 included brief introductory essays written by each of Typomundus's twelve international judges and three of its organizers, ${ }^{47}$ alongside black-and-white reproductions of the selected works. The selected works were grouped under familiar divisions in the catalogue, such as: Book Jackets, Posters, Reports, and Printing for Commerce, and other categories expressing more radical forms of production-Experimental, Miscellaneous Typography, Lettering and Calligraphy, and Typography in Architecture.

Carl Dair, who had been the force behind the national Typography exhibitions, also served as a judge and organizer for Typomundus. His role became pivotal for the organization when American authorities refused to grant entry visas to Typomundus judges from Eastern European countries in the wake of the Cold War. ${ }^{48}$ The evaluation of submissions by the international jury, originally slated to take place in New York, was relocated to Toronto thanks to Dair's efforts. ${ }^{49}$

That the prominent role of Canada in this international showcase was due to US entry restrictions for Eastern European judges exemplifies the tension between the organizers' utopian notions of international cooperation and the reality of Cold War politics. Typomundus endeavoured to exemplify many of the same ideals of international cooperation and inclusiveness that had earlier been articulated by Dair in conjunction with the Typography exhibitions. The very name Typomundus, a Latin phrase that translates as type of the world, reveals the exhibition's global aspirations. Embossed in gold on the exhibition catalogue cover, the epithet was illustrated to represent this idea symbolically: the letter 0 in typo has been replaced by an image of a globe. | fig. 6| Underscoring this inclusiveness, the catalogue text appears in three languages: English, French, and German. 


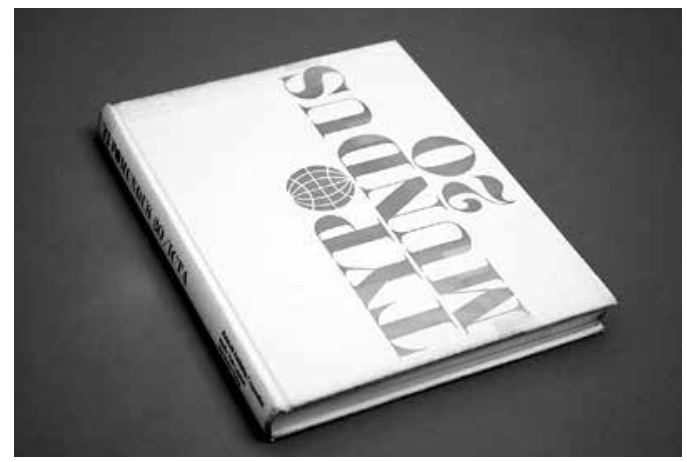

Figure 6. Typomundus 20 catalogue cover. From International Center for the Typographic Arts, Typomundus 20. Source: "Unit Editions," Flickr, Typomundus 20 (set), www.flickr.com/photos/ uniteditions.
Figure 7 (facing page, left). George Maciunas, articles 219 and 458,1963 and 1964 respectively. From International Center for the Typographic Arts, Typomundus 20. From the author's personal collection (photo: author)

Figure 8 (right). Articles 450 to 454. From: International Center for the Typographic Arts, Typomundus 20. From the author's personal collection (photo: author).
50. ICTA 1966, XVIII.

51. Ibid., XXVII.

52. Marshall McLuhan, The Gutenberg Galaxy: The Making of Typographic Man (Toronto, 1962), 217.

53. ICTA 1966, XX. McLuhan was also indirectly involved in the Canadian Typography exhibitions. In 1960 he was invited to address the typographic community in Toronto as keynote speaker at the awards luncheon for Typography 60 (Donnelly, "Mass Modernism," 62) According to a Globe and Mail article from the time, McLuhan used the opportunity of this speech to address "the way in which the once technical skills of typographers were being developed as part of a wider communications revolution" (quoted in Donnelly, "Mass Modernism," 62). The message to the design community in Toronto was that the changing nature of communication in society offered opportunities to transform the role of the designer beyond its traditional roots in craft.
Additionally, Typomundus included designers from outside of Europe and North America on both its jury and in its selected works, strengthening (albeit weakly) the exhibition's claim to global inclusiveness. Japanese designer Hiromu Hara served as the single Typomundus jury member from Asia. Hara, along with the other jurors, helped select a number of works by Japanese designers for inclusion in the exhibition and catalogue. Czechoslovakian juror Oldrich Hlavsa underscored the show's inclusive aims in his introduction, calling for the exhibition to mark "the beginning of a bond among the typographic designers of the world." ${ }^{50}$ Hara expressed similar inclusive aspirations for the exhibition while commenting implicitly on the Cold War politics responsible for the shift in venue, noting, "it is desirable for all of us to cooperate on the international scale regardless of differences in ideologies or political beliefs." ${ }^{51}$

The prominent emphasis on the social role of typography as a means of international communication and cooperation reflected another Canadian contribution to design debates at this time, namely the influential theories of University of Toronto professor and media theorist Marshall McLuhan. Interest in McLuhan's ideas was part of a larger shift in understanding the importance both of communication technologies and of the communicator's role in a mass society. In particular, McLuhan's theories of the global village, where "the vernacular ... affords a glimpse of social unity" 52 were influential among the jurors and designers involved with Typomundus. A number of Typomundus jurors referred to the importance of typography's value as communication in their introductions to the catalogue, and American judge Lou Dorfsman cited McLuhan's ideas on typographic man directly, devoting a whole paragraph to a quotation from McLuhan's newly published book The Gutenberg Galaxy. ${ }^{53}$

\section{The Art/Design Divide}

Like the Canadian Typography shows, Typomundus promoted reflection on distinctions between design's experimental and communicative roles, and between high and mass culture, adopting practices from the realm of fine art that favoured aesthetics over functionality. At the same time, discussions in Typomundus focused more on typography's expanded role as a communications medium, rather than the debates on art and craft prevalent in the Canadian Typography shows. Indeed, the premise underlying Typomundus was that 

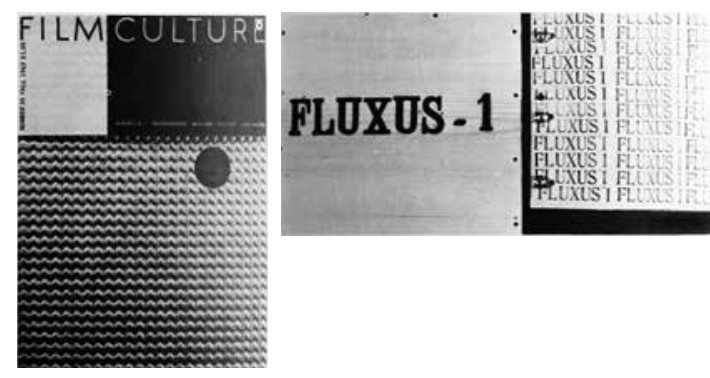

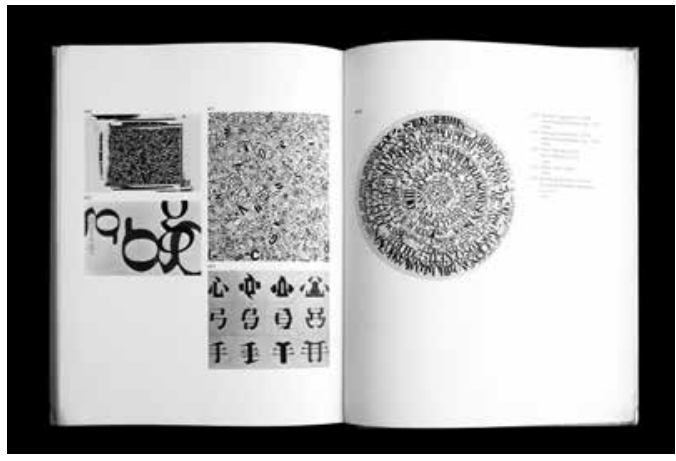

typographic work was to be judged primarily on aesthetic grounds, a view that may be attributed to a change in the cultural status of the profession from the 1950 s to the mid-1960s. The challenge was no longer to distinguish design from craft, but to reconcile the artistic aspirations of designers with the functionalist demands of the International Style.

Typomundus adopted standards of aesthetic judgment in an attempt to bridge distinctions between the fine and applied arts and increase the cultural value of graphic design. Typomundus president Aaron Burns encouraged jurors to evaluate the exhibition's submissions according to aesthetic standards such as "form, beauty, appeal, and excellence of typographic artistry." ${ }^{54}$ In a response to this dictum, Piet Zwart commented that aesthetic considerations were "undefinable, intuitable, and purely subjective," and that they "escape all concrete rules and regulations." 55 Zwart's comments reveal his association with the International Style, with its emphasis on objectivity and rationality, and opposition to decoration and the expression of the subjective experience of individual designers.

Typomundus sought an elevated status for design not only by association with artistic practices, but with artists themselves. Two works by Fluxus artist George Maciunas (articles 219 and 458) were exhibited as part of Typomundus and included in the catalogue. | fig. 7| Maciunas's work is here evaluated solely according to aesthetic considerations, with at least one of his submissions lacking any connection to design as a functional/commercial art. In a further effort to elevate the status of the graphic design profession, Typomundus included a number of categorical divisions that promoted experimental and artistic works of design. The exhibition did not seek to disavow design's links to commerce and the marketplace, but sought to enhance and expand the perceived scope for graphic design among both designers and the general public. Examples are items 450 to 454 , | fig. 8 | which resemble concrete poetry, and which were never destined for design's traditional role in the marketplace. Debates concerning the relationship of form to function were not quelled by the increasing prominence of artistic standards and experimental work. Instead, they intensified. Lou Dorfsman, for example, weighed in on the side of functionality, referring to typography as one of only two "practical arts, the other being architecture." ${ }^{56}$ These debates supported the continued reflection and scholarship by practitioners on problems of special interest to design. 


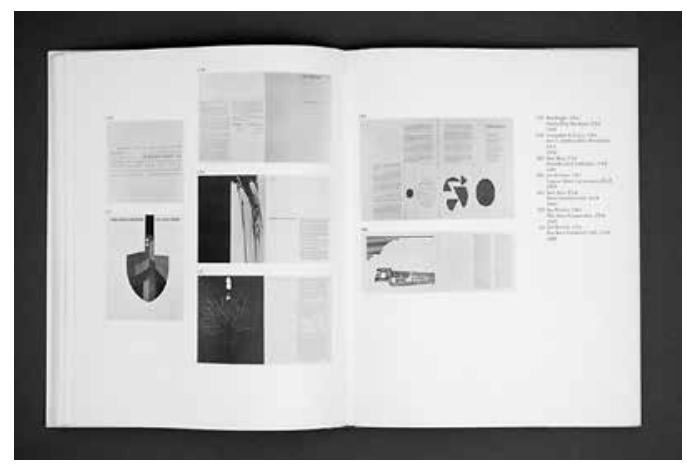

Figure 9 (left). Articles 178 to 184. From International Center for the Typographic Arts, Typomundus 20. Source: "Unit Editions" Flickr, Typomundus 20 (set), www.flickr.com/photos/ uniteditions.

Figure 10 (right). Paul Renner, designer, article 534, 1924. From: International Center for the Typographic Arts, Typomundus 20. From the author's personal collection (photo: author)

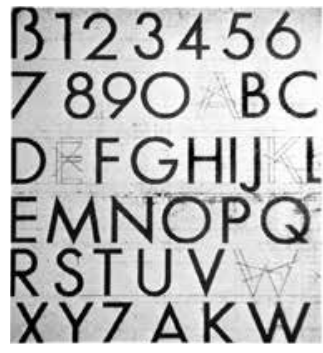

\section{Universal Standardization}

In light of the high percentage of Europeans sitting on its international jury (nine of twelve jurors were European), it is not surprising to find that Typomundus promoted the International Style both implicitly and explicitly. Swiss designer Hans Neuberg, one of the founding editors of the design journal Neue Grafik/New Graphic Design/Graphisme actuel devoted to the Style, served on Typomundus's jury. German judge Anton Stankowski could have ben referring directly to attributes belonging to the International Style when he claimed "Functional and clean typography" as one sought-after factor in the judging process. ${ }^{57}$

While the vision of the international design community represented by Typomundus promoted cohesiveness through consensus around professional standards, in practice the exhibition revealed a tension between the competing goals of inclusion and standardization. As a collective exhibition with international participants, Typomundus explored the possibility of introducing a universal design standard into a diverse community of nations. In its intrinsic support for the International Style, with its standardization of design forms, Typomundus effectively decreased the visible diversity of national styles. Works from North America and a few European countries dominated Typomundus. Inclusive goals gave way to exclusivity, as shown in the page spread illustrating articles 178 to 184 . | fig. 9 | This example is one of a number of pages comprised completely of works from American designers. The "World of Typography" that Typomundus claimed to represent included only a single work from Africa, and was completely absent of work from South America, China, India, or any Middle-Eastern country, with the exception of Israel. ${ }^{58}$

Some of the difficulty lay in the different typographic character sets used in many languages and the diverse printing histories in those countries. In his introductory text, Hiromu Hara expressed regret over the fact that Japan was

57. Ibid., XXIX.

58. It should be noted that there is no evidence of submissions from any of these omitted areas or countries, nor is there evidence that the call for submissions was published or distributed in these areas.

59. ICTA 1966, XXVII.

6o. Ibid., XXVII. the only Asian nation represented in the exhibition. Despite this, Hara also voiced a desire for commonality in communication design through the global influence of a modernist aesthetic, claiming, "The new typography ... has had a strong influence on Japanese designers." ${ }^{59}$ Hara went on to lament the limited availability of "European" typefaces in Asian countries, and voiced the hope that Japanese designers would be better represented in future competitions based on an increased use of typography with European letters. ${ }^{60}$ For 
61. Ibid., xxv.

62. The exception being the Typography 64 exhibition, which judged submissions created over the two-year period between June 1962 and June 1964 (TDC 1964).

63. ICTA 1966, XVI.
Hara, it seems, standardization and a common language and character set were seen as a way forward, despite his seemingly contrary desire for greater national diversity among exhibition contributors.

Dair used his written introduction to underscore the socio-economic inequality among nations and its effect upon participation in Typomundus. Describing the example of a submission by a designer from "one of the newly independent African states" alongside the "lavish commercial productions of designers in the affluent societies," Dair noted that the work of the former suffered by the comparison. ${ }^{61}$ Nonetheless, he claimed it was the creation of common standards, and not individual achievement, that was the driving force behind both Typomundus and the ideal growth of the profession. Such evidence of a clash between the goals of inclusion and standardization plagued Typomundus and revealed a gap between its inclusive rhetoric and its geographical exclusions. This gap resulted, however, in a particular type of professional cohesion.

\section{Cohesion through Exclusion}

Typomundus sought different means of elevating the profile of graphic design and promoting professional standards than those employed by the Canadian Typography exhibitions. Unlike the latter, which represented the best works from a single year, ${ }^{62}$ Typomundus promoted itself as encompassing the best work from the first 65 years of the twentieth century. Typomundus jurors succeeded in elevating certain works of graphic design from the past, including Piet Zwart's cover for a film series monograph from 1933, Alvin Lustig's New Directions book jacket from 1947, and Paul Renner's 1924 sketches for the Futura typeface, | fig. 10 | into a partial history of typographic design in the twentieth century. The identity Typomundus sought to create for international designers was based on a selective history of twentieth-century design as embodied in a limited repertoire of exemplary works. Despite attempting an objective sampling of the whole of twentieth-century design to that point, the vast majority of work selected for inclusion in Typomundus was drawn from the period immediately preceding the exhibition. As the catalogue demonstrates, over three-quarters of the works selected for inclusion were created in the five years from 1960 to 1964 . Further, fully ninety-two percent of the final works included in the Typomundus catalogue originated between 1950 and 1964 . Instead of the "cross-section of the typography of the twentieth century" 63 that Max Caflisch and the other jurors envisioned, Typomundus effectively rendered itself an arbiter of the style of its time. Indeed, the jury included only a single work to represent the first twenty years of the twentieth century, an unidentified newspaper spread attributed to Canadian designer L.C. Hughes.

While purporting to represent an inclusive history of a global community, the organizers of Typomundus instead consolidated the international design community around a particular vision of typographic excellence drawn from their own period and ranks. The final selections for the Typomundus exhibition included a disproportional number of jury members' own works, including twenty-six pieces by American juror Lou Dorfsman, twelve by Oldrich Hlavsa, and seven by Piet Zwart. This further attests to the partial nature of the jury's judgment and to the insularity of the design community that allowed it to 
64. This essay focuses on explicit practices of exclusion, that is, acts of selective representation among the works of self-described typographers, designers, and artists. By contrast, the underrepresentation of certain social, ethnic, and geographic groups within those professions may be seen as an implicit type of exclusion. Such implicit exclusions and their underlying causes fall outside the scope of this essay. present its own standards as universal. The fact that Typomundus (like the Canadian Typography exhibitions) largely excluded the work of female designers can be viewed as a reflection of male dominance within the profession at the time. Taken in conjunction with the exhibition's stated goals, however, Typomundus must again be seen to depart de facto from one of its key organizational principles. ${ }^{64}$

The particular mode of professional cohesion achieved by Typomundus was therefore derived mainly through exclusion. Instead of representing commonality in heterogeneity, Typomundus distilled a limited, selective variety of styles into a single, authoritative cultural voice. Ironically, it is by diverting from its stated ideology and systematically excluding alternative voices that the exhibition achieved cohesion among those designers whose works were accepted. Whereas the value of the International Style was still being debated in the Canadian Typography exhibitions, in Typomundus the Style became institutionalized as a positive standard through a combination of geographical, historical, and personal biases in the selection process. These exclusionary practices played in favour of Canadian designers, many of whom conformed to the International Style in their work, and allowed Canada to position itself as a leading contributor to the emerging profession.

\section{Conclusion}

Both the Typomundus and Typography exhibitions contributed to the growth of the graphic design profession in Canada by strengthening the sense of a cohesive professional identity among Canadian designers. The Canadian Typography exhibitions achieved this through several mechanisms, including bringing professionals from across Canada together and exposing them to the international graphic design community, advancing professional standards and ensuring their dissemination through expert judging and education, and perhaps most importantly, by promoting reflection on the status and role of the graphic designer with respect to high art, mass communication, and society at large.

Typomundus operated along many similar lines of social and professional cohesion, including aesthetic judging and debates reflecting upon the social role of the designer. The form of cohesion articulated in Typomundus, however, resulted above all from its promotion of the International Style to the exclusion of all others. Three different but complementary levels of exclusion functioned in Typomundus: geographical, historical, and personal, all leading to a gap between the exhibition's rhetoric of diversity and its actual execution. And yet, the rhetoric of diversity was no less essential to professional cohesion than were the practices of exclusion. The standardization of style was aided by Typomundus's inclusionary rhetoric, as explicit exclusion would presumably have encountered resistance. The rhetoric of diversity and inclusion, in other words, allowed the organizers to present the works selected for the show as a genuine cross-section of the typography of the twentieth century, while promoting their own vision of design standards as universal.

The process of cohesion instigated by both exhibitions was aided by Canada's unique circumstances in the 1950 s and 1960s. With its diverse group of émigré design professionals, its relatively peaceful diplomacy, and McLuhan's 
increasingly influential scholarship, Canada was ideally situated to play a leading role in shaping the identity of the emerging profession. Canadian graphic designers, motivated in part by utopian ideals of universal cooperation, formed their professional identity around the desire to contribute to universal communication and global culture. These desires were reflected in the Typography exhibitions and in the debates that surrounded them. Held during a key period of development for the graphic design profession, the exhibitions produced more than a mere body of works and accompanying commentaries. They helped produce and publicize a new discourse and historical narrative that allowed Canadian typographers and communication designers to think of themselves as belonging to a unified, distinct community. To fully understand the social dynamics of the profession during this crucial period, additional research is required to trace the development of graphic design across broader geographies and cultures.

ACKNOWLEDGEMENTS The author would like to thank Keith Bresnahan for his continuing support and Brian Donnelly for his ongoing encouragement and access to his invaluable archive of Canadian graphic design works. I am also indebted to Patricio Davila and an anonymous reviewer for valuable comments. Work on this article was supported by the Social Sciences and Humanities Research Council (SSHRC) Joseph-Armand Bombardier CGs Master's scholarship. 